Marc L. Greenberg

University of Kansas

\title{
Multiple Causation in the Spread and Reversal of a Sound Change: Rhotacism in South Slavic
}

\begin{abstract}
Prispevek obravnava spremembo $\check{z}>r$ (»rotacizem«) v južnoslovanskih jezikih. Zaradi zapletene razvrstitve spremembe tako po jezikovni geografiji kot po besednih vrstah se zdi, da se je ne da razložiti z enim samim vzrokom. Ugotovlja se namreč, da je sprememba nastala zaradi vrste glasoslovnih in analognih vzrokov; umikanje inovacije proti zahodu pa so očitno povzročili sociolingvistični dejavniki.

The paper treats the change $\check{z}>r$ ("rhotacism") in the South Slavic languages. Its complex distribution both in its linguo-geographical dimension and parts of speech suggests that its development cannot be explained in terms of a single cause. It is found that a combination of phonological and analogical factors must account for the initial change and its spread; sociolinguistic factors apparently account for its retreat towards the west.
\end{abstract}

\section{Introduction}

0.1 In Ivić's map phonological isoglosses in the W-SSl dial area (= the dials corresponding to the $\mathrm{Sn}, \mathrm{Cr}$, Bs and Srb standard languages), the isogloss of the form može $>$ more 'can' (3rd pers sg) stands as a representative of the change $\check{z}>r$ (Ivić 1958: 31). The isogloss, which roughly bisects the area mentioned, seems clear cut, though, in fact, the change is much better represented in the $\mathrm{W}$ part of this territory than the E part. Nor is it clear whether the change is a phonetic or a morphological one. The complications with regard to this sound change are many and there is no consensus on the details of its development. To illustrate, the change occurs regularly in the form mentioned, but does not occur as might be expected in, for example, oženiti se 'to wed'. It occurs also in forms in which the phonetic motivation is either absent or isolated, for example, morati : mora 'must' (inf : 3rd pers sg). From the point of view of linguistic geography, the forms in which the change has occurred become sparser to the east as one approaches the može > more isogloss, yet forms such as morati extend beyond the isogloss. Within a given dial there may be variation, for example, both može and more are attested in the dials of NW-Bs (Vujičić et al. 1979: 146) and in E-Slavonian localities that are transitional to the Šumadija-Vojvodina dialect (Ivić 1990: 87-89, 93). The change and the peculiarities of its distribution have been explained by some scholars as a result of phonetic change and by others through morphological analogy. In this paper it will be shown that neither of this forces can be discounted in accounting for the results of this change - not only are both explanations essentially correct (though with some amendment) - but they both must have worked together to give rise to the particular pattern of change in part of the areal ( $\mathrm{Sn}, \mathrm{Cr}$ ). It will also be suggested that the reversal of this change in part of the areal ( $\mathrm{Srb}, \mathrm{Mac}, \mathrm{Bg}$ ) can be accounted for by 
considering sociolinguistic factors. In the continuation, the results of the change will be referred to as " $r$-forms," in order to avoid prejudging the motivations for the change. ${ }^{1}$

0.2 The distribution of the change is restricted to a small number of lexical items and categories, as sketched here: ${ }^{2}$

0.2.1 The present tense of the verb moči 'to be able': morem, moreš, more, as well as prefixed forms pomoč/ći : pomore 'to help', premoč/ći : premore 'to overcome'; the form morda 'perhaps' $(<* m o z ̌ e ~ d a)$. The area of the this change includes Sn, Ča, Kaj as well as Što Ikavian, most of Ijekavian and W-Ekavian, including the environs of Novi Pazar.

0.2.1 In Sn and $\mathrm{Cr} / \mathrm{Bs} / \mathrm{Srb}$ in the verb morati : moram, moraš, mora 'to be obligated, must', apparently a derivative of $m o c ̌ c ́ c i$.

0.2.3 Complementizers and adverbs built with the enclitic particle -že, e.g., Sn kakor $(<* k a k o-\check{z}(e))$ 'as', kdor $(<* k b d o-z ̌(e))$ 'who, whoever'; vendar $(<* v e m-d a-\check{z}(e))$ 'however'; it appears in Što in the form jer 'because'.

0.2.4 Time expressions in some Sn dialects, e.g., nocộr 'tonight' (Istria), nicor 'idem' (Styria).

0.2.5 The adv. bore 'pitifully, poorly', presumably built from the vocative of bog 'God', cf. boremi 'my God!'; the adj. derived from this, boren 'poor'. This is found in $\mathrm{Sn}$ and $\mathrm{Cr}$ dialects.

0.2.6 The present tense of the verb gnati 'to drive (cattle).' The present tense form renem is found in Inner Carniola, as well as a new infinitive built on this stem ręnit (attested in Inner Carniola, Kras and Upper Carniola); the prefixed forms odrene, prerene, prorene, proreneio are attested in the late 16th c. from Upper Carniola. A blend of gnati and renem is found in the forms rrȩniti : yręenem (Kras) (Ramovš 1924: 295, Bezlaj 1977: 175). NW-Bs dialects have izrènuti, nè more (Vujičić et al. 1979: 52, 97). Skok finds that the Romanian form "porni nije od porinoti nego je pognati $=$ pornati $(14$. v.), kako se vidi iz porni oile 'tjerati ovce', Mihai porni cete spre a lua in goană pe duşman 'Mihalj je poslao čete da u potjeri zauzmu neprijatelja'. Odatle porneală’ (Skok I: 575).

0.3.1 The majority opinion is that the source of the change is phonetic. Ramovs explains the change in articulatory terms: "prehod $\check{z}>r$ (znan tudi shrv. in bolg.) doživi le intervokalični $\check{z}$, če mu sledi vokal $e$, ki je tvorjen s pridvignjenim delom jezikove ploskve proti sprednjemu trdemu nebu..." (1924: 294; Vondrák 1924: 459-460). Following this formulation, Bezlaj assumes that the form rénem (Inner Carniola) arose under the conditions stated: "do rotacizma je prišlo v sintagmah tipa krave žene" (1977: 175). Similarly, Cvetko Orešnik finds that "der Rhotacizmus gerade bei tere begann", the form attested in the FF and simultaneously the earliest attestation of the phenomenon (1987-88: 439). It is generally assumed that the change resulted in the alternation $\check{z} / r$, and that this $r$ spread in word formation (see

\footnotetext{
${ }^{1}$ I am grateful to Andrew Corin (UCLA), Bill Darden (University of Chicago), Marko Snoj, Metka Furlan (Inštitut za slovenski jezik, ZRC SAZU), and an anonymous reviewer for helpful comments on earlier drafts of this paper.

${ }^{2}$ A thorough review of the evidence is found in Cvetko Orešnik 1987-8. I therefore limit my statement of the facts to the minimum necessary for the purposes of the present paper.
} 
Cvetko Orešnik 1987-88: passim). A further condition, that the segment appear in an unstressed syllable, has also been claimed (Cvetko Orešnik 1987-88: 434).

0.3.2 A fundamentally different scenario is presented by Ivančev, who claims that rhotacism was not a phonological change at all, but was caused by analogical spread from the relative adjective kateri. In the summary of his article he says: "Imajući u vidu da je domen pojave u leksičkom pogledu krajnje ograničen, možemo smatrati da su reči s $r$ iz $\check{z}$ u slovenačkom i srpskohrvatskom jeziku slučajevi leksikalizacije pri kojoj zamena $\check{z}$ sa $r$ ne bi mogla da se obrazloži delovanjem nekog fonetskog procesa kako se to obično tumači. Pretpostavlja se da je u uslovima semantičko-funkcionalne jednakosti leksičke građe, -že/ž u većini odnosnih reči, po uticajem analogije zamenjeno sa -re/r. To je prvenstveno bilo u rečima kateri, eventualno kater, $-a,-o$ " (1981). This view assumes the metanalysis of kater- into pronominal (kate-) and relativizing (-r-) morphemes. The new relativizing suffix then spread and overtook relativizing constructions in -že (e.g., iže). While such a development is a possible explanation for forms of the conjunctions and complementizers of the type kar, kdor, Ivančev's theory fails to provide a plausible mechanism for virtually all of the remaining types. Nor does it deal with the difficulties of motivating the spread even in the category he adduces. This theory is stretched the furthest in attempting to explain forms such as bori, boren, more, žen- as due to the same mechanism (ibid.: 25); in these cases there is no model for analogy. The author concedes: "makar če neštata tuk ne sa osobeno jasni" (loc. cit.). It is obvious that Ivančev's theory cannot be accepted as stated. However, with some qualifications, we shall demonstrate that there is a place for part of this analogical explanation in the fuller picture of the rhotacism phenomenon.

\section{Phonological factors}

1.1 As we have seen above, the question of whether the $r$-forms can be considered a result phonological or morphological change in SSl is fraught with ambiguity. Since the descriptive facts do not point to a definitive answer, it is reasonable to ask whether the possibility of phonetic change is systemically motivated. Andersen, noting the parallel between the change $r^{\prime}>\check{r}$ in WSl and the W-SSl $\check{z}>r$ change, views each of these as natural changes in consonantal and vocalic languages, respectively. With respect to the $z>r$ change, "since both stridency and voicing shift the acoustic structure of a consonant towards that of a vowel, it is easy to understand how learners of a language might evaluate voiced, strident, continuous obstruents as realizations of liquids" (1978: 6). Thus the parallelism arises when the marked value of the feature + vocalic is replaced by the unmarked value, as in Table 1 . 
Table 1

\begin{tabular}{|c|c|c|c|}
\hline \multirow[b]{2}{*}{ SSl } & $|\check{Z}|$ & \multirow[b]{2}{*}{$>$} & $/ \mathrm{r} /$ \\
\hline & $\begin{array}{l}-\operatorname{voc}(\mathrm{M}) \\
+\operatorname{cons}(\mathrm{U})\end{array}$ & & $\begin{array}{l}\overline{+\operatorname{voc}(\mathrm{U})} \\
+\operatorname{cons}(\mathrm{M})\end{array}$ \\
\hline & $/ \mathrm{r}^{\prime} /$ & & $/ \check{\mathrm{r}} /$ \\
\hline WSl & $\begin{array}{l}+\operatorname{cons}(\mathrm{U}) \\
+\operatorname{voc}(\mathrm{M})\end{array}$ & $>$ & $\begin{array}{l}+\operatorname{cons}(\mathrm{U}) \\
-\operatorname{voc}(\mathrm{U})\end{array}$ \\
\hline
\end{tabular}

This simplification is a specific example of the general tendency by which, according to Isačenko, “[v]okalische Sprachen weisen die Tendenz auf, Konsonanten zu vokalisieren" and "die konsonantischen Sprachen entwickeln nicht nur keine sonantischen Konsonanten, sondern sie unterdrücken sogar die natürliche Sonorität der Konsonanten" (1939-40: 72, 73). Thus the change parallels other changes that have increased the number of vocalic constrasts in $\mathrm{Sn}$ and $\mathrm{Cr} / \mathrm{Bs} / \mathrm{Srb}$ (connection with intensive contact with Romance dialects) in contradistinction to the reduction of such contrasts in N-Sl. This explains why the change is not found in WSl, although it probably occurred at a time when the connection between WSl and SSl had not yet been completely interrupted. For these reasons it seems plausible to assume that the change has a phonetic component.

1.2 To the extent that the change is phonetic, the chronology of -V̌̌e- $>-\mathrm{Vre}$ must be later than the first palatalization of velars (6th c) and perhaps earlier than the merger of the result of this change with the reflex of $* z$ ' from deiotation (8th c), since the latter remain unaffected. The change must have also preceded the writing of the FF, where the change is first attested. The FF attest to a stage in which fluctuation between $\check{z}$ - and $r$-forms could still occur, e.g., tere 'also' $(2 \times)$, ise 'which', mosem 'I can' $(2 \times)$, tomuge 'to this very' tige (= [tiže]) 'these same'.

1.2.1 It is not clear whether stress played a role in the change, as we find Sn dialect vrè 'already' (cf. StSn žê), which contradicts the notion that stresslessness in the syllable is a precondition of the change. It may be, however, that in this instance the $r$-form was an extension from other temporal expressions (see 2.3).

\section{Morphological factors}

\subsection{Verbs}

2.1.1 In the case of gnati : rene, the source of the change is ambiguous, since there is the possibility of contamination with the verb *rinoti to push'. However, unless the $r$-forms of -žene $\left(t^{\prime} b\right)$ were already in place, there would not have been a formal match to pave the way for analogy. Alternatively, one might argue that the $\check{z} / r$ alternation existed elsewhere in the lexicon and so the possibility of its extension to any morpheme containing $\check{z}$ was opened. However, since the number of lexical items in which the alternation participated is so restricted, this scenario seems unlikely. Therefore it seems more likely that the identification with *rinoti arose after the phonetic change had taken place in compounds of the type dorene. This led to an alternation between the simplex žene and the compound dorene. From this alternation, the distribution could have given rise to three logical outcomes: (1) the alt- 
ernation could have remained; (2) žene could have been generalized, effectively reversing the change; or (3) (do)rene could have been generalized. In the western areas (Kras, Inner Carniola, Ča, parts of Što), outcome (3) occurred, where the simplex morpheme was replaced by analogy to rene. This regularization may be reinforced by identification with *rinoti. Elsewhere outcome (2) occurred.

2.1.2 The verb može/more lacks an alternation between $\check{z}$ and $r$ in the present tense and therefore the possibility of the change being reversed due to leveling can be ruled out. In contrast to -gnati:-žene, the environment in question is non-alternating and this may in part account for the fact that the change is found over a much wider area for more than -rene.

2.1.3 If we contrast the outcome in each of these verbs we find that the greater areal of more in contrast to -rene is in accord with the principle that "change develops earlier in uniform environments because they represent the context for change more consistently than alternating evironments" (Timberlake 1978: 326; see also 1981). See Table 2.

\section{Table 2}

\begin{tabular}{ll}
\hline uniform & alternating \\
\hline morem $,-e \check{s}, \ldots$ & ženem, $-e \check{s}, \ldots$ I \\
dorenem, - ěs,$\ldots$ \\
r(e) & ženiti se $;$ *oreniti se \\
\hline
\end{tabular}

2.1.4 The verb morati occurs over an even greater area, including those areas of Sto that have može. The reason for this appears to be that the verb was derived directly from more and then imported from the $\mathrm{W}$ dialects E-wards. The formal model for the derivation is unclear, though its semantic motivation is apparently due to language contact, cf. OHG muozan 'can/must' > MoG müssen 'must' (see further Musić 1923; Ramovš 1924: 294; Grubor 1925-26; Snoj 1997: 354). This active construction replaced nominal constructions of the type $\mathrm{R}$ ja dolžen 'I must' in a parallel fashion to $\mathrm{Cz}$ musim, a direct borrowing and adaptation of $\mathrm{G}$ müssen. Lexical innovation seems to be an additional factor in the retention of the change (see 3.4.2, 4.1).

\subsection{Pronouns and conjunctions}

2.2.1 The possibility of analogy proceeding from the relative pronoun, proposed by Ivančev, cannot be ruled out. However, the analogy is hardly as straightforward as Ivančev suggests and a number of things need to be explained before such a proposal can be considered. The first major difficulty is that the forms as they appear today - Sn kdó/kdọ, katéri; Cr tkö, kòjī; Srb kö, kòjī - do not match and as such cannot have given rise to analogy. This raises the question of the shape of the forms in question at a time early enough to have preceded the change $\check{z}>r$. The comparative evidence suggests fairly unambiguously that the CSl input must be $* k$ b̆to (< IE *ko $\left.k^{u}-s+t o d\right)$ : $\mathrm{R} k t o ́, \mathrm{Ukr}, \mathrm{Br} x t o ́$, Po chto, $\mathrm{Cz} k d o(\mathrm{OCz} k t o)$, Srb kö, 
$\mathrm{Bg}$, Mac ko, US štó, LS chto. Although it is tempting to connect $\mathrm{Cz} k d o$, Sn kdó and assume these to be a common innovation, the Sn dialect evidence suggests that the $-d$ - arose in independently in both territories, e.g., Rož $h t u{ }^{3},{ }^{3}$ Zilja túa, Prekmurje $\check{s} t \ddot{o}^{4}{ }^{4}$ In C-Sn the $-d$ - from the temporal and spatial interrogatives $(* k(b) d$ $k d a j, k d e / k j e)$ is thought to have spread to *k(b)to (Bezlaj 1977: 27). ${ }^{5}$ This innovation cannot have preceded the change of $\check{z}>r$ as we see in the form nihčê 'no one' $\left(<* n i-k b t z-z ̌ e\right.$, cf. Po nikt 'idem'), a form common to both Sn and Kaj. ${ }^{6}$

2.2.2 With regard to the relative adjective, the situation is complicated at the $\mathrm{CSl}$ level as well as in Sn and Kaj (the form apparently disappeared in Medieval Srb). The Sl languages point to a number of CSl variants: *koterb (OCS koteryi, Sk kotery), *kotorb (R kotóryj); *kbterb (Cz ktery), *kbtorb (Po który); *katerb (StSn kateri). Of these, only the first can be connected directly with the IE material, Gr póteros, Li katràs, kataràs (Vilnius), Skt kataráh. The StSn form is the most narrowly localized of these variants and may have its origins either in akanje or the influence of the pronoun kák 'what kind', cf. kateri (Trubar, 16th c), kateri, ketiri (Dalmatin, Megiser 16th c), katir (Pohlin, 18th c), kateri (Gutsmann, 18th c) (Bezlaj 1977: 23). The form *koterb survived as a relic in the compound neikoteri 'certain ones' alongside nekateri in the language of Trubar, though as a pronominal adjective the form kateri is used exclusively (Ramovš 1920: 274-275, 1952: 97; Rigler 1968: 185; Hamp 1980: 98) and is known also in Ča and Kaj koteri (Belostenec, Habdelić, Voltiggi, Stulli, Budinić, 16-18th cc) (Skok: 1977: 113). The forms UC kẹr, kérga (nom, gen sg), Pkm štềri, Kaj štári (Bednja) indicate a starting point in *kbtèr which may have arisen under the influence of $* k b t o{ }^{7}$ Of the three forms that are common to $\mathrm{Sn}$ and $\mathrm{Cr} / \mathrm{Bs} / \mathrm{Srb}$, the one that gained widespread productivity by the 9 th c appears to be *kbterb. If Ivančev's proposal is to be accepted, then the starting point for the spread of $-r$ from the relative adjective originates in the analogy that must have developed from the juxtaposition of (the now archaic forms) $* k b t o / b$

\footnotetext{
${ }^{3}$ Rigler cites the form with falling intonation $(h t \hat{u})$ for Breznica pri Št. Jakobu v Rožu (Rigler 1981: 198).

${ }^{4}$ The innovation is known also in Kaj, e.g., Ozalj dôlgdo, in place of the usual form $\check{s} t o$. The form $\check{s} t o$ in US, Kaj and Pkm is not the continuation of CSI *čbto, but represents the change $h t>$ $\check{s} t$, cf. Pkm štẹtti 'to want' < *xъtếti. Merger was avoided in US by means of a quantity contrast, viz. što 'what' : štó 'who'. In Kaj and Pkm it was avoided by the replacement of *čbto with a new pronoun built from the complementizer $k \ddot{a}<* k a ̂ k\left(<\mathrm{IE} * k^{u} e h_{2}\right.$, cf. Lat qua) and the pronominal formant $*_{-} j_{b}$ (see Snoj 1997a).

${ }^{5}$ This is a question of relative chronology entailing the removal of one of the sources of analogy in the later history of a change. For a typological parallel, note the $\mathrm{Sn}$ and $\mathrm{Cr}$ dial change of *bez $>$ brez under the influence of črez. In the C-Sn dials the form črez has become čez by a regular phonological rule simplifying clusters of the type $* \check{c} r, * \check{z} r>\check{c}$, $\check{z}$, thus giving $\check{c} e z$, brez in StSn.

${ }^{6}$ The reconstruction of $* n i-k z t z$ in $\mathrm{Sn}$, Kaj the proto-form is questionable, though can be based on the received forms in Sn and Po. It may be that the root developed a variant parallel in

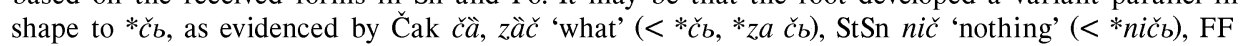
nizce. Alternatively, it could be assumed that the $o$ was subject to an exceptional early reduction, i.e., from a form *ni-kzto-že (Snoj 1997: 382).

${ }^{7}$ The Srb and $\mathrm{Cr}$ standard form $k \grave{j} \overline{\bar{l}},-\bar{a},-\bar{o}$ are forms rebuilt on the oblique form $k o j-$ (OCS $k y$, kojego), a 13th-c development (Skok 1972: 112) which played no role in the formation in question.
} 
: *kbter $b$. Moreover, this can only be understood in a narrower sense than Ivančev intended, as this marker could have spread only with the meaning imparted by the function of $-r$ as a relativizing particle.

\subsection{Time expressions}

2.3.1 One may be tempted to assign to the Sn dialect form nocộr 'tonight' (Dekani pri Kopru nicûar, Škofije nacûar, Vodnik (Sty, 19th c) nizor (Šivic-Dular 1982: 415)), the same type of formation that arose in other temporal adverbs, such as $\mathrm{Sn}$ dánas, $\mathrm{Cr} / \mathrm{Bs} / \mathrm{Srb}$ dànas 'today' $(<* d b n \grave{s} s b \leq * d b n b+s b)$, Sn nocọj ${ }^{8}$ in which the elements $*_{-S b} *_{-} j b$ added a temporal deictic function to the base form. On this view the $r$-element is regarded as an enrichment to the list of deictic particles used to build temporal adverbs. Such a proposal would not be without merit in light of the semantics of $\check{z} e$ in $\mathrm{N}-\mathrm{Sl}$, where the meaning can be deictic (cf. $\mathrm{R}$ on že 'the very same one (masc.)'. However, this meaning is not characteristic in SSI. Instead, this - $r$ may be an extension of the model built from *věčer $b$, in which the $r$-element is original (Gr hésperos, Lat vesper, Lit vãkaras). This word developed two different meanings in SSl dialects, one a noun meaning 'evening' and the other an adverb meaning 'in the evening', which after the fall of the jers became differentiated by

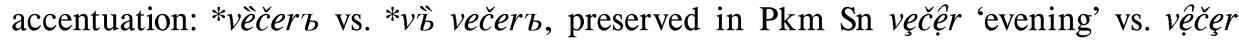
'in the evening' (StSn večêr with both meanings). That this - $r$ - was interpreted both as a stem ending and as a deictic marker is evidenced by its removal in Sto věče , as

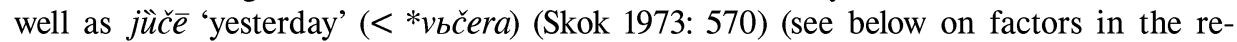
versal of the change). The temporal deictic meaning of $-r$ - may have been enriched further by identification with both older *ütro 'morning' (StSn jútro, Pkm vü̈tro, $\mathrm{Cr} / \mathrm{Bs} / \mathrm{Srb}$ jütro) and newer Sn osorệj 'at this time, at this hour' $(<* o b$ seji urě < Lat hōra, Sn dialect osorẹ, osovrê, osevrệj (Bezlaj 1982: 258)). Thus it is as likely that the $-r$ in nocôr is a result of the spread of $-r$ marking temporal deixis from words like *v̋̆ večer $b$ as from $-r(e)<* z ̌ e$.

\subsection{Other}

2.4.1 The preservation of the form bore, and its derivatives, may have retained its shape due to taboo. Skok observed that "[k]ako je kršćanstvo tabuiralo riječ bog prema židovskom uzoru da se Jahveh ne upotrebljava nego jehova, često se ne upotrebljava bog u potpunoj fonetici nego se $g$ zamjenjuje sa $r$. Mjesto bogme govori se borme, tako ti bora mjesto boga; oj ti bora ti; za bora miloga" (Skok I: 191). This notion is confirmed by the Pkm usage, in which börme 'my God!' is a more polite form of bögme (Novak 1996: 22).

\section{Reversal of the change}

3.1 An intriguing factor in the development of $r$-forms is that its areal in the Medieval period was much more widespread than it is today. In $\mathrm{StCr} / \mathrm{StBs} / \mathrm{StSrb}$ the

\footnotetext{
${ }^{8}$ The mysterious $-c$ - in this form is a matter of some debate: Šivic-Dular finds this to be a relic of WSI infiltration (1982); Furlan assumes the form results from the simplification of a diminutive *not'bcä from *nöt’b (1993: 220-2). She points out that an older explanation, deriving the base from an already deictic *not'bsb is untenable in light of Istrian najco, in which $-j c$ could not have arisen from $*_{-t}$ 'bs- (ibid.).
} 
relics of the change are few, which essentially reflects the fact that $\breve{C a}$ and Kaj literary traditions were abandoned in favor of Sto. The relics include the conjunction jer, which is connected with the older formation from complementizers built from *j- (related to OCS iže 'that, which' masc sg, ježe neut sg) that became replaced by those built on *čbto and $* k o j b$, a process that was underway in the 14th-15th cc (Grickat 1975: 287); the verb morati; and the word takoder 'also' (alongside the alternant takode). The evidence in $\mathrm{Bg}$ and Mac is sparse, but the phenomenon is known there, too, e.g., Bg dorí 'even' $(<* d o-z ̌ e)$, Mac duri 'up to, until', Bg (dialect) dordéldordéto 'until' $(<*$ do-že-dě $), \mathrm{Bg}$ tere 'and', Bg bar/bárelbarém/barím 'at least' $(<* b a-z ̌ e)$ (examples from Miklošič, Vondrák, Lavrov, cited in Cvetko Orešnik 1987-1988: 435-436). As mentioned above, it was borrowed (from Bg?) into Romanian from the present tense of pogbnati, attested in the 14th c (Skok 1971: 575). One can agree with Cvetko Orešnik and her predecessors that "man muss bei diesen Beispielen besonders vorsichtig sein" (loc. cit.), as they may well have been the result of infiltration from Serbian usage. Nevertheless, it is clear that at a certain point in the high Medieval period, $r$-forms were on the wane in the E. Not only did they cease to be productive, but they also seem to have become systematically removed from the lexicon.

3.1.1 It is not surprising that the polarization of productivity is found in the conjunctions. As Ivić has observed, "od gramatičkih reči najviše razlika između praslovenskog stanja i današnjeg srpskohrvatskog pokazuju veznici. Objašnjenje moramo tražiti u činjenici da su od svih tih reči veznici, naročito oni u podređenim rečenicama, najzavisniji od stepena razvijenosti apstraktnog mišljenja, što znači i od opšteg kulturnog nivoa sredine" (Ivić 1991: 316). One does not have to look far to realize that in Slavic writings of the 10th-14th cc there is a striking variety in the forms that replace older subordinating structures (such as the dative absolute or "dative of subordination," on which see Andersen 1970). But why do the $r$-forms prevail in Sn and $\mathrm{Cr}$ and recede in $\mathrm{Srb}$, Mac and $\mathrm{Bg}$ ? As a working hypothesis, let us assume that in the formation of new complementizers, $r$-forms gained a high prestige value in a $\mathrm{W}$ milieu and a low prestige value in the $\mathrm{E}$ milieu, i.e., corresponding to S-Slavs under the influence of Rome vs. Constantinople. ${ }^{9}$ If this hypothesis proves correct, it helps explain why the development is more pervasive in $\mathrm{Sn}$ and $\mathrm{Cr}$ and undergoes attrition in Srb (and, to the extent that they are relevant to the picture, $\mathrm{Mac}$ and $\mathrm{Bg}$ ).

3.2 It is unfortunately very difficult to trace the details of the development in $\mathrm{Sn}$, because there is a gap in the textual evidence in precisely the time frame under investigation. However, for the beginning and end points of the development, the picture is fairly clear, so that it is possible to surmise with a reasonable degree of assurance what occured in the dark period. In the 10th $\mathrm{c}$ the FF attest to the beginnings of a competition between $r$-forms and $\check{z}$-forms. The conjunction tere 'and, also' occurs twice; but other forms show unchanged $\check{z}$, e.g., ise 'which', mosem 'I can' (occurs twice), tomuge 'to this very' tige, choiseih 'which' gen $\mathrm{pl}(<* k y$-že $+i x ъ){ }^{10}$ The number of examples here is too small to conclude anything except that $r$-forms

\footnotetext{
${ }^{9}$ The situation is reminiscent of Labov's famous study of $r$ (less)-forms in New York City (that the segment in question is $r$ is, of course, entirely fortuitous). Rather than class distinctions, however, the values would have been assigned to religious-ethnic communities (see Labov 1972).

${ }^{10}$ Forms from the Freising Folia are quoted from Bernik et al. 1993.
} 
were possible variants at this stage. By the early 14th c., as evidenced by the Celovec/Rateče Ms.," the $r$-forms in subordinating conjunctions have been generalized: Otscha nass kyr sy wnebessich... 'Our father who art in heaven ...', odpufti nam dalge nafse kakor yno my ... 'forgive us our trespasses as we .... Cf. also the 15th c Stična Ms. zkemer 'with which' $(2 \times)$, kakur 'as' $(8 \times)$, kadar 'when' (3×), kygar 'whom' acc/gen sg.

3.3 In contemporaneous $\mathrm{Cr}$ documents, $r$-forms are general on an equal footing with those found in $\mathrm{Sn}$, albeit combined with partially different material. For example, in the $\mathrm{Cr}$ Glagolitic Paris Codex (Split, 14th c) we find more $(4 \times)$, morešb, premorešb 'you overcome', arelar' $(5 \times)$ 'for, because', jureljur' 'already', tereltrb 'and', ništare 'nothing', nikogare 'nobody' gen sg, nigdarb 'never', nig'děrb 'nowhere', nigdorb 'nobody' (Malić 1972: 131). Examples of ž-forms in Cyrillic $\mathrm{Cr}$ works are numerous, though these are found in conjunction with other features of the OCS Cyrillic tradition, e.g., Povaljska listina (Brač, 1250) Tako jesm slišal da sije zem$l(j) e$ ježe vy držite ... 'Thus I have heard that these lands that you hold ...' (Moguš 1993: 25; Malić 1988: 38ff). In locally-colored texts $r$-forms abound, e.g., Š. Menčetić (Ča-Što koinè, 15th c): ozriv se jak jelin ter ončas pođe tja, ter gorči ner pelin $i$ čemer ostah ja (Vončina 1988: 82).

3.4.1 As was pointed out above in connection with the morphological motivation for $r$-forms in the relative adjective $* k b t e r b$, in Što there was a marked tendency to generalize other forms, in particular $k o i(<* k o j-\leq * k b j b$ 'which') (Kopečný, Šaur and Polák 1980: 389). Subordinating pronominal forms built from *jb- (iže, etc.) became replaced by the general complementizer *čbto (̌sto), which began in the 14-15th cc to compete with koi (Grickat 1975: 286-91). Since *k'bter'b failed to be selected as a relative marker, it had no chance of becoming a model for analogical developments (in contrast to the developments in Sn, С̆a, Kaj, discussed above). However, this did not eliminate the subordinating conjunction jer $(e)(<*$ ježe), which is a relic of the older layer of $* j b$-forms (Grickat 1975: 72). The survival of this form is apparently connected with the widening of its semantics: OCS ježe functioned narrowly as a complementizer indicating causative subordination, e.g., čjuždaaxo se ježe kъšnjaaše 'they were surprised that (s)he was late', whereas MoSrb jer ranges in function from strictly causatives meanings to (essentially paratactic) general, summarizing meanings, e.g., tako je bolje, jer šta bi ti radio ako bi slučajno saznao za tu nesreću! 'it's better this way for what would you do if you had found out about this misfortune!' (Grickat 1975: 126, 134-5 and passim). The new functions are far removed from the original meaning (anaphora), indicating that jer was felt to be operating natively and independently in the system.

3.4.2 In Srb Što the process seems to have been reversed, leading to hypercorrections of the type vèčêr $>$ vèč $\bar{e}$, jùče $r>j u ̄ c ̌ \bar{e}$ (Skok III: 570), in which the $-r$ element was identified with $-r<-z ̌(e)$. This gives some support to the notion that $-r-$ became identified with a style that came to be felt as foreign to Što speakers. Note, however, that this applies only to productive types. This gives a plausible explanation for the reduction of the number of lexical items in which $r$-forms occurs in Stokavian: they persist most consistently in those lexical items in which the $r$-element is

\footnotetext{
${ }^{11}$ Forms from the Celovec/Rateče and Stična Mss. are cited from Mikhailov 1997: 101-102.
} 
non-alternating and in which it has become lexicalized (morati, jer) and lost elsewhere.

\section{Conclusion}

4.1 To sum up, the phenomenon of rhotacism had a number of intersecting factors determining its spread and reversal. The change occurred, first, only under narrowly defined phonemic conditions, thus limiting it to a small part of the lexicon. It persisted best in uniform environments and tended towards reversal in alternating environments. Its chances of persistence were increased if a semantically similar form with $-r$ was available $(* k(b)$ ter $-\geqq k d o$, kdor; rine $\geqq$ rene; večer $\geqq$ nocor). Forms that were high style $(\mathrm{H})$ (conjunctions) were prestigious in the $\mathrm{W}$ and thus remained productive; the markedness was reversed in the $\mathrm{E}$, and these correspondingly $\mathrm{L}$ forms tended to be removed, except for those that became integrated into the system in such a way that they were no longer identified as part of the same semantic field or level of prestige (jer, morati). The factors are summarized in Table 3 .

\section{Table 3}

\begin{tabular}{lc}
\hline Factor & Favors retention? \\
\hline Alternating & - \\
Uniform & + \\
H style & $+(\mathrm{W}),-(\mathrm{E})$ \\
Analogical & + \\
possibility & \\
Semantic & + \\
innovation & + \\
\hline
\end{tabular}

4.2 With respect to chronology, the following rough scenario may be proposed: (1) 7-8th cc. - phonetic innovation $\check{z}>r$, (2) ca. 8-11th cc. enrichment of categories containing $r$-forms and E-ward expansion of lexical items containing $r$-forms; (3) $10-14$ th $\mathrm{cc}$. attrition of productive $r$-forms spreading $(\mathrm{E} \rightarrow \mathrm{W})$.

4.3 Further study, in the form of a survey of the appearance of $r$-forms in Medieval S-Sl texts, will be necessary to test the scenario put forth in this paper. One hopes that a more precise account of the paths of lexical enrichment and relative chronology would emerge from such a study. This should, in turn, shed light on the social value of the variants, which will help to illuminate another aspect of the society of Medieval S-Europe.

\section{Abbreviations}

Bg = Bulgarian, Bs = Bosnian, $\mathbf{C}=$ central, Ča $=$ Čakavian, $\mathbf{C r}=$ Croatian, $\mathbf{E}=$ east(ern), FF $=$ Freising Folia, G = German, Kaj $=$ Kajkavian, LC $=$ Lower Carniolan dialect, $\mathbf{L i}=$ Lithuanian, $\mathbf{L S}=$ Lower Sorbian, Mac = Macedonian, $\mathbf{M o}=$ Modern, $\mathbf{N}=\operatorname{north}(\mathrm{ern})$, OCS $=$ Old Church Slavic, OHG = Old High German, 
$\mathbf{P k m}=$ Prekmurje dialect of Slovene, $\mathbf{P o}=$ Polish, $\mathbf{R}=$ Russian, $\mathbf{S}=\operatorname{south}(\mathrm{ern}), \mathbf{S} \mathbf{l}$ $=$ Slavic, $\mathbf{S n}=$ Slovene, Srb $=$ Serbian, $\mathbf{S S l}=$ South Slavic, $\mathbf{S t}=$ Standard, Što $=$ Stokavian, Sty $=$ Styrian dialect, UC $=$ Upper Carniolan dialect, US $=$ Upper Sorbian, $\mathbf{W}=$ west(ern), $\mathbf{W S 1}=$ West Slavic

\section{References}

Aleksić, R. 1937. Prilozi istoriji kajkavskog dijalekta. Južnoslovenski filolog 16: 1-98. Andersen, H. 1970. The Dative of Subordination in Baltic and Slavic. Baltic Linguistics (ed. by T. F. Magner and W. R. Schmalstieg): 1-9. University Park and London: The Pennsylvania State University Press.

- -. 1978. Vocalic and Consonantal Languages. Studia Linguistica Alexandro Vasilii Filio Issatschenko a Collegis Amicisque Oblata: 1-12. Lisse: The Peter de Ridder Press.

Bajec, A. 1954. Prislovni paberki. Slavistična revija 5-6: 195-226.

Bernik, F., et al. 1993. Brižinski spomeniki. Znanstvenokritična izdaja (= SAZU, Dela 39). Ljubljana: SAZU.

Bezlaj, F. 1977 (I: A-J), 1982 (II: K-O), 1995 (III: P-S). Etimološki slovar slovenskega jezika. Ljubljana: Mladinska knjiga.

Bidwell, Ch. E. 1961. The Chronology of Certain Sound Changes in Common Slavic as Evidenced by Loans from Vulgar Latin. Word 17: 105-127.

Cvetko Orešnik, V. 1987-88. Zum Rhotazismus im Südslawischen. Klagenfurter Beiträge zur Sprachwissenschaft 13-14: 433-446.

Furlan, M. 1993. O nekaterih slovenskih dvojnicah tipa rakitje : rokitje. Slavistična revija 41: 219-229.

Grickat, Irena. 1975. Studije iz istorije srpskohrvatskog jezika. Belgrade: Narodna biblioteka SR Srbije.

Grubor, Đ. 1925-26. Morati. Južnoslovenski filolog 5: 150-161.

Hamp, E. P. 1980. Slovenski koteri, katéri, in *saus-, Briž. slov. v uzmazi in smag-. Slavistična revija 28/1: 97-101.

Ilešič, F. 1925-26. »Moći« i »morati« u slovenačkom jeziku. Južnoslovenski filolog 5: $162-170$.

Isačenko, A. 1939-40. Versuch einer Typologie der slavischen Sprachen. Linguistica Slovaca 1/2: 64-76.

Ivančev, S. 1981. Za rotacizma v slovenski i sbrboxbrvatski ezik. Zbornik za filologiju i lingvistiku Matice srpske 24/1: 23-25.

Ivić, P. 1958. Die serbokroatischen Dialekte: Ihre Struktur und Entwicklung, 1: Allgemeines und die štokavische Dialektgruppe. The Hague: Mouton.

- -. 1990. O starim izoglosama na tlu slavonskog dijalekta. Croatica-Slavica-IndoEuropæa (ed. by G. Holzer) (= Wiener slavistisches Jahrbuch, Ergänzungsband VIII): 83-93. 
- -. 1991. Iz istorije srpskohrvatskog jezika. Niš: Prosveta.

Kopečný, F., V. Šaur and V. Polák. 1980. Etymologický slovník slovanských jazyků. Slova gramatická a zájmena, sv. 2: spojky, částice, zájmena a zájmenná adverbia. Prague: ČSAV.

Labov. W. 1972. Sociolinguistic Patterns (= Conduct and Communication, 4). Philadelphia: University of Pennsylvania Press.

Malić, D. 1972. Jezik najstarije hrvatske pjesmarice (= Znanstvena biblioteka Hrvatskog filološkog društva 1). Zagreb: HFD.

- -. 1988. Povaljska listina kao jezični spomenik (= Znanstvena biblioteka Hrvatskog filološkog društva 17). Zagreb: HFD.

Mikhailov, N. 1997. I Monumenti Linguistici Sloveni dell "Epoca dei Manoscritti" (= Studi Slavi, Dipartimento di Linguistica Università degli Studi di Pisa, No. 6). Pisa: ECIG.

Musić, A. 1923. Moči i morati u slovenskom jeziku. Rad JAZU 227: 1-58.

Novak, F., and V. Novak. 1996. Slovar beltinskega prekmurskega govora. Murska Sobota: Pomurska založba.

Ramovš, F. 1920. Opazke k slovanskim tvorbam pronominalnega debla *qwo-. Časopis za jezik, književnost in zgodovino 2: 274-276.

- -. 1924. Historična gramatika slovenskega jezika. Ljubljana: Znanstveno društvo.

- -. 1936. Kratka zgodovina slovenskega jezika. Ljubljana: Akademska založba.

- -. 1952. Morfologija slovenskega jezika. Ljubljana: Univerzitetna študijska komisija.

Rigler, J. 1968. Začetki slovenskega knjižnega jezika (= SAZU Razred za filološke in literarne vede, Dela 22, Inštitut za slovenski jezik 10). Ljubljana: SAZU.

- -. 1981. Breznica pri Št. Jakobu v Rožu (Friessnitz; OLA 147). Fonološki opisi srpskohrvatskih/hrvatskosrpskih, slovenačkih $i$ makedonskih govora obuhvaćenih Opšteslovenskim lingvističkim atlasom (= Akademija nauka i umjetnosti Bosne $i$ Hercegovine, Posebna izdanja 55, Odjeljenje društvenih nauka 9) (ed. by P. Ivić, et al.): 193-200. Sarajevo: ANUBiH.

Shevelov, G. Y. 1965. A Prehistory of Slavic. The Historical Phonology of Common Slavic. New York: Columbia University Press.

Šivic-Dular, A. 1982. Sln. nocój in njegove vzporednice v slovanskih jezikih. Slavistična revija 30: 415-418.

Skok, P. 1971 (I: A-J), 1972 (II: K-poni'), 1973 (III: poni²-Ž), 1974 (IV: Kazala). Etimologijski rječnik hrvatskoga ili srpskoga jezika. Zagreb: JAZU.

Snoj, M. 1997. Slovenski etimološki slovar. Ljubljana: Mladinska knjiga.

- -. 1997a. Kaj je kaj? Škrabčeva misel II. Zbornik s Simpozija '96: 187-192. Nova Gorica: Frančiškanski samostan Kostanjevica.

Timberlake, A. 1978. Uniform and Alternating Environments in Phonological Change. Folia Slavica 2: 312-328.

- -. 1981. Dual Reflexes of $* d j$ in Slavic and a Morphological Constraint on Sound Change. International Journal of Slavic Linguistics and Poetics 23: 25-54. 
Vondrák, W. 1924. Vergleichende slavische Grammatik, I. Band. Lautlehre und Stammbildungslehre. Göttingen: Vandenhoeck \& Ruprecht.

Vujičić, D., D. Brozović, M. Desić, and A. Peco. 1979. Govori sjeverozapadne Bosne. Bosanskohercegovački dijalektološki zbornik II: 7-157. Sarajevo: Institut za jezik i književnost.

Prispelo junija 1998, sprejeto novembra 1998

Received June 1998, accepted November 1998

\section{Različni vzroki za širitev in umik fonetične spremembe: rotacizem $\mathrm{v}$ južnoslovanskih jezikih}

Prispevek obravnava spremembo $\check{z}>r$ (»rotacizem«) v južnoslovanskih jezikih, kot se najde npr. v sedanjiku glagola *može $\left(t^{\prime} b\right)>$ sln. mọ́re, hrv./bos. nar. möre, $\mathrm{v}$ oziralnih veznikih $(* k a k o \check{z}(e)>\operatorname{sln}$. kakor), v različnih prislovnih tvorbah, npr. (*bože > bore), v nekaterih sln., hrv./bos. narečjih tudi v sedanjiku glagola (*grnna$t i:) * z ̌ e n e(t b)>$ rene. Izvor te spremembe je različno obravnavan kot fonetična ali oblikoslovna (analogna) sprememba, vendar pa nobena od razlag ne pojasnjuje omejene uresničitve spremembe (tj., sprememba je omejena na majhno število leksemov in slovničnih kategorij) in zelo različnih arealov spremembe $v$ vsakem posameznem primeru, $v$ katerem je do nje prišlo. $\mathrm{V}$ pričujočem prispevku se dokazuje, da je izvor spremembe fonetičen in da izhaja iz težnje, ki podpira razločevalne lastnosti pri samoglasnikih (za razliko od severnoslovanskih razvojev), kar je teza, ki se navezuje na predvojno Isačenkovo razpravo. Vseeno pa se da širitev spremembe in njen umik delno razložiti z oblikoslovnimi dejavniki. Eden od dejavnikov je ta, da stalno okolje (npr. sedanjik morem, moreš ...) vspodbuja njeno širitev, v nasprotju s spremenljivimi okolji (-žene/-rene), ki so povzročila njen umik ali zaustavitev. Drugi dejavnik je širitev $-r$-ja kot produktivnega oziralnega veznika in časovnega znaka po modelu oblik *kbtelo-r- oz. veče-r. Zdi se, da je pri medmetu borme dodatno vlogo pri ohranjanju oblike $\mathrm{z}$ - $r$ - igrala tabuiranost. Umik spremembe $\mathrm{v}$ štokavščini je imel lahko stilistične vzroke, saj so bile oblike $\mathrm{z}-r \mathrm{v}$ nasprotju $\mathrm{z}$ oblikami $\mathrm{z} \check{z}(e)$ občutene kot izrazito zahodne, katoliške. Ta opažanja izhajajo iz dejstva, da oblike $\mathrm{z}-r$ izginevajo prav $\mathrm{v}$ tistih primerih, $\mathrm{v}$ katerih so bile produktivne $\mathrm{v}$ čakavščini, kajkavščini in slovenščini, tj. v oziralnih veznikih in časovnih prislovih. In ne nazadnje, najbolje so ohranjene oblike, ki predstavljajo semantične inovacije, npr. morati, jer, in to celo $\mathrm{v}$ štokavščini, kjer so oblike $\mathrm{z}-r$ - leksikalizirane.

\section{Multiple Causation in the Spread and Reversal of a Sound Change: Rhotacism in South Slavic}

The paper treats the change $\check{z}>r$ ("rhotacism") in the South Slavic languages, such as that, e.g., found in the present tense of the verb *mozze(trb) > Sn mọ́re, $\mathrm{Cr} /$ Bs dialect möre; complementizers, e.g., *kako ž(e) > Sn kakor; in various adverb- 
ial formations, e.g., *bože > bore; and, in some $\mathrm{Sn}$ and $\mathrm{Cr} / \mathrm{Bs}$ dialects, the present tense of the verb (*grnati:) *žene(tb) > rene. The origin of the change has been treated variously as a phonetic or a morphological (analogical) change, though neither explanation can account for the limited realization of the change (i.e., it is restricted to a small number of lexical items and grammatical categories) and the vastly differing areals of the change for each item in which it occurs. The present paper argues that the origin of the change is phonetic and follows from a tendency to favor vocalic distinctive features (in contrast to N-Sl developments), a notion that goes back to a pre-War paper by Isačenko. Nevertheless, the spread of the change, and its reversal, can be partially explained by morphological factors. One factor is that uniform environments (e.g., the present tense morem, moreš ...) favor its spread vs. alternating environments (-ženel-rene) which have reversed or inhibited it. Another factor is support for the spread of $-r$ as a productive complementizer and temporal marker on the models of metanalyzed forms *kbte/o-r- 'which' and *veče-r 'evening', respectively. Taboo seems to play an additional role in preserving $r$-forms in the interjection borme 'my God!'. The reversal of the change in Štokavian may have been due to stylistic considerations, where $r$-forms were felt to be distinctly western, Catholic, in contrast to $\breve{z}(e)$ forms. This observations follows from the fact that $r$-forms disappear in Štokavian in precisely the forms in which they were productive in Čakavian, Kajkavian and Slovene, namely, the complementizers and temporal adverbs. Finally, those forms which represent semantic innovations, such as morati 'must', jer 'for, because' are best preserved, even in Štokavian, where the $r$-forms are lexicalized as such. 